\title{
The GIST of Thermal Stresses of Cast Iron Castings
}

Peter Futáš ${ }^{1)}$, Imrich Jelč²), Iveta Vaskovái ${ }^{1)}$, Gabriel Fedorko ${ }^{3)}$, Vieroslav Molnár ${ }^{3)}$, Peter Kačmáry ${ }^{3)}$

${ }^{1)}$ Department of Ferrous and Foundry Metallurgy, Faculty of Metallurgy, Technical University of Košice, Park

Komenského 14, Košice, 040 01, Slovakia.peter.futas@tuke.sk, iveta.vaskova@tuke.sk

${ }^{2)}$ IT TRADING, s.r.o., Expertises of the department of metallurgy, smelting and casting metals, Kysucká 14, Košice, 04001, Slovakia.jelc@atlas.sk

${ }^{3)}$ Logistic institute of industry and transport, Faculty BERG, Technical University of Košice, Park Komenského 14,

Košice, 040 01, Slovakia.gabriel.fedorko@tuke.sk, vieroslav.molnar@tuke.sk, peter.kacmary@tuke.sk

This paper deals with problems concerning to the lifetime of thermal-stressed castings used in general practice. It is necessary to know in details the purport of thermal-stress of cast iron as well as conditions of the thermal-stress (the level of operational temperature, or its fluctuations, i.e. thermal duty cycle) for the right choice of chemical composition and structure (macro and micro) of a material. The successful solution of this problem is now provided by means of computer (simulation programs), including optimization of construction of components (castings). It requires comprehensive theoretical analysis of the purport of the thermal stress i.e. impact of various physical parameters to its origin, course and size.

Keywords: cast iron, heat stress

\section{Acknowledgements}

This work was supported by the Scientific Grant Agency of The Ministry of Education of the Slovak republic VEGA by grant number 1/0922/12 and 1/0498/11.

\section{References}

[1] LICKFETT, H. (2012). Gussproduktion 2010 - globale Trends. In: Giesserei 99, Vol. 2012, No. 4, pp. 154 - 157 , ISSN: 0016-9765.

[2] ANWAR, M. Y. (2006). A study on thermal cracking of cast iron. In: 70th Annual Session Proceedings, Pakistan Engineering Congress, pp. 414 - 422. http://pecongress.org.pk/images/upload/books/Paper677.pdf

[3] MOONESAN, M., HONARBAKHSH RAOUF, A., MADAH, F., HABIBOLLAH ZADEH, A. (2012). Effect of alloying elements on thermal shock resistance of gray cast iron. In: Journal of Alloys and Compounds, Vol. 503, pp. 226 - 231, ISSN 0925-8388.

[4] MANESH, A. A. I., SEGERLIND, L. J. (1991). Simulation of heat transfer and stress analysis of continuous casting. In: Archive of Applied Mechanics, Vol. 61, No. 6 - 7, pp. 393 - 403, ISSN: 0939-1533.

[5] MAIJER, D., COCKCROFT, S., JACOT, A. (2000). Modeling of microstructure and residual stress in cast iron calender rolls. In: Metallurgical and Materials Transactions A, Vol. 31, No. 4, pp. 1201 - 1211, ISSN 1073-5623.

[6] L. BUMBÁLEK. Zbytková napětí určovaná pomocí Barkhausenova šumu, Strojírenská technologie a Munufacturing Technology, 2004, 11-15 s.

[7] JELČ, I. (1983). Výroba hutníckych a t’ažkých odliatkov. VŠT Košice, 1983, 974 s.

[8] GEDEONOVÁ, Z., JELČ, I. (2000). Metalurgia liatin. HF TU Košice, 2000, 288 s.

[9] Magmasoft 4.4: Magmairon Module, Simulation of Microstructural Modeling in Cast Iron, 2005.

[10] KIM, H. S. (2009). Analysis of thermal behavior during equal channel multi-angular pressing by the 3-dimensional finite volume method. In: Materials Science and Engineering: A. Vol. 503, No. 1-2, pp. 130 - 136, ISSN 09215093.

[11] ZEMAN, P., MÁDL, J. Simulace doformací v obrobku softwarem AdvantEdge 3.6, Strojírenská technologie a Munufacturing Technology, 2002, 23-27 s

[12] BOŽEK, P., KORŠUNOV, A. I. (2012). Advantages of INS control systems. In: TechMat '12, pp. 1 - 7. http://dspace.upce.cz/bitstream/10195/48767/1/BozekP_AdvantagesOfINS_2012.pdf 